Instructions for authors, subscriptions and further details:

http://ijep.hipatiapress.com

\title{
Dialogic Readers Children Talking and Thinking Together about Visual Texts
}

Lirio Flores Moncada $^{1}$

1) University of Deusto, Spain

Date of publication: June $24^{\text {th }}, 2016$

Edition period: June 2016 - October 2016

To cite this review: Flores Moncada, L. (2016). [Review of the book Dialogic Readers Children Talking and Thinking Together about Visual Texts by Maine, F.] International Journal of Educational Psychology, 5(2), 220-222. doi: 10.17583/ijep.2016.2147

To link this review: http://dx.doi.org/10.17583/ijep.2016.2147

\section{PLEASE SCROLL DOWN FOR ARTICLE}

The terms and conditions of use are related to the Open Journal System and to Creative Commons Attribution License (CC-BY). 
IJEP - International Journal of Educational Psychology, Vol. 5 No. 2 June 2016 pp. 220-222

\section{Review}

Maine, F. (2015). Dialogic Readers Children Talking and Thinking Together about Visual Texts. London: Routledge.

What is happening when children co-construct meaning while making a dialogue and interacting? In the book, Dialogic Readers Children Talking and Thinking Together about Visual Texts, Fiona Maine responds this inquiry and provides a wider clarification in this field. Fiona Maine is a lecturer in literacy education at the University of Cambridge, expert in children's critical and creative thinking as they engage with a range of text modes (written, visual and moving-image). She has also years' experience working as a teacher and with teachers, as they develop their own practice.

First, she plunge us in a reading where the reply arises from seven blended chapters. The result is exposed through an exhaustive and detailed theoretical review on language of co-construction, children's critical and creative response to text, dialogic transaction between text and readers and the use of language as a tool for creating a social cohesion between readers. Furthermore, her study includes an analytical framework that illuminates the dialogic and co-constructive functions of the language used by children as they make meaning together from visual text.

The book is supplemented with case studies, which in addition to clarifying and exemplifying the theoretical arguments, give meaning to the whole explanation. It should be stressed that throughout the text, educational notions and practices of how to implement them at the classroom level primary aim are proposed. It remains to say that the author argues how important is performing reading through visual and moving images as they are essential in this 21 st century notions of literacy.

In the core of this text we find the reason why dialogue through moving images is so important. On one hand, she poses that the solution to this problem helps to develop children's criticism abilities and convergent thinking, as they are free to express their own thoughts, reasons, hypotheses, ideas and/or results about visual text. So these thoughts are confronted and 
evaluated by their interlocutor. On the other hand, she proposes the story spinning, being here where the creative and divergent process is carried out itself. Creative, because each participant explains and argues what is happening from his own social and cultural context. And divergent, because on theses meaning-making processes, agreement is not necessary.

To evaluate processes that occur in these two modes of thinking, the author rightly takes up bases provided by the Vygostskian and Piagetian theories, which she applies objectively in a consistent way, as they are indispensable to understand dialogic reading.

Maine reminds us in an informed manner how thought is produced from social interaction as well as the potential for cognitive development depends on the "Zone of proximal development" (Vygotsky, 1978).

Likewise on the hypotheses, reasons, explanations and resolutions given by children in their visual text reading, Piaget's processes of accommodation and assimilation are clearly identified (Piaget, 1952). Extracts as the following dialogue: "02 Gina: Yeah...there's lots of men and they kid of [seem to be]...03 Sophie: [Reminds me of] Mary Poppins...04 Gina: Hmm, but a male version...." are a good example of these processes.

The implications of the contributions offered by the book to educational context, specifically for classroom practice, are critical and develop in children cognitive processes as critical thinking, creativity, responsibility, collaborative and reflective spirit, among many others skills.

The book promotes values for future generations. It teaches how to dialogue and respect different ideas, hypotheses, and opinions. It promotes conflict resolution and teaches how to listen and how to reach the right to be heard in freedom. It must be taken into account that dialogue opens a possibility for improvement in any context, especially in education. It is important to note that the use of visual texts (images, moving images and picture books) reduces barriers to dialogue that arise due to misunderstanding of words and written texts.

Finally, I found inspiration in Maine's words, which personally shocked me and pushed me to keep reading her book: "[...] we should stop and listen carefully what children say". 
222 Flores -Dialogic Readers Children Talking and Thinking Together about Visual Texts [Book Review]

\section{References}

Maine, F. (2015). Dialogic Readers Children Talking and Thinking Together about Visual Texts. London: Routledge.

Piaget, J. (1952). The origins of intelligence in children. International Universities Press, Inc.

Vygotsky, L. S. (1978). Mind in society: the development of higher psychological processes. Cambridge: Harvard University Press.

Lirio Flores Moncada Faculty of Psychology \& Education University of Deusto lirioflores@deusto.es 